5. Booth, F. W. \& Thomason, D. B. Molecular and cellular adaptation of muscle in response to exercise: perspectives of various models. Physiol. Rev. 71, 541-585 (1991).

6. Hood, D. A. Contractile activity-induced mitochondrial biogenesis in skeletal muscle. J. Appl. Physiol 90, 1137-1157 (2001)

7. Gollnick, P. D. et al. Enzyme activity and fibre composition in skeletal muscle of untrained and trained men. J. Appl. Physiol. 33, 312-319 (1972).

8. Jarvis, J. C. et al. Fast-to-slow transformation in stimulated rat muscle. Muscle Nerve 19, 1469-1475 (1996).

9. Chin, E. R. et al. A calcineurin-dependent transcriptional pathway controls skeletal muscle fibre type Genes Dev. 12, 2499-2509 (1998).

10. Naya, F. J. et al. Stimulation of slow skeletal muscle fibre gene expression by calcineurin in vivo. J. Biol. Chem. 275, 4545-4548 (2000).

11. Bigard, X. et al. Calcineurin co-regulates contractile and metabolic components of slow muscle phenotype. J. Biol. Chem. 275, 19653-19660 (2000).

12. Olson, E. N. \& Williams, R. S. Remodeling muscles with calcineurin. Bioassays 22, 510-519 (2000).

13. Lehman, J. J. et al. Peroxisome proliferator-activated receptor $\gamma$ coactivator-1 promotes cardiac mitochondrial biogenesis. J. Clin. Invest. 106, 847-856 (2000).

14. Yoon, J. C. et al. Control of hepatic gluconeogenesis through the transcriptional coactivator PGC-1. Nature 413, 131-138 (2001)

15. Esterbauer, H. et al. Human peroxisome proliferator activated receptor gamma coactivator 1 (PPARGC1) gene: cDNA sequence, genomic organization, chromosomal localization, and tissue expression. Genomics 62, 98-102 (1999).

16. Lin, J. et al. PGC-1ß: a novel PGC-1 related transcription coactivator associated with host cell factor. J. Biol. Chem. 277, 1645-1648 (2002)

17. Johnson, J. E., Wold, B. J. \& Hauschka, S. D. Muscle creatine kinase sequence elements regulating skeletal and cardiac muscle expression in transgenic mice. Mol. Cell. Biol. 9, 3393-3399 (1989).

18. Ogilvie, R. W. \& Feeback, D. L. A metachromatic dye-ATPase method for the simultaneous identification of skeletal muscle fibre types I, IIA, IIB and IIC. Stain Technol. 65, 231-241 (1990).

19. Grange, R. W. et al. Functional and molecular adaptations in skeletal muscle of myoglobin-mutant mice. Am. J. Physiol. Cell Physiol. 281, C1487-C1494 (2001).

20. Wu, H. et al. MEF2 responds to multiple calcium-regulated signals in the control of skeletal muscle fibre type. EMBO J. 19, 1963-1973 (2000).

21. Wu, H. et al. Activation of MEF2 by muscle activity is mediated through a calcineurin-dependent pathway. EMBO J. 20, 6414-6423 (2001).

22. Calvo, S. et al. Fibre-type-specific transcription of the troponin I slow gene is regulated by multiple elements. Mol. Cell. Biol. 19, 515-525 (1999).

23. Black, B. L. \& Olson, E. N. Transcriptional control of muscle development by myocyte enhancer factor-2 (MEF2) proteins. Annu. Rev. Cell Dev. Biol. 14, 167-196 (1998).

24. Delling, U. et al. A calcineurin-NFATc3-dependent pathway regulates skeletal muscle differentiation and slow myosin heavy-chain expression. Mol. Cell. Biol. 20, 6600-6611 (2000)

25. Michael, L. F. et al. Restoration of insulin-sensitive glucose transporter (Glut4) gene expression in muscle cells by the transcriptional coactivator PGC-1. Proc. Natl Acad. Sci. USA 98, 3820-3825 (2001)

26. Nakayama, M. et al. Common core sequences are found in skeletal muscle slow- and fast-fibre-typespecific regulatory elements. Mol. Cell. Biol. 16, 2408-2417 (1996).

27. Goto, M. et al. cDNA cloning and mRNA analysis of PGC-1 in epitrochlearis muscle in swimmingexercised rats. Biochem. Biophys. Res. Comm. 274, 350-354 (2000).

\section{Acknowledgements}

We thank R. Sanders Williams and A. Buonanno for providing reporter constructs, and J. Lawitts for generating transgenic mice. This work was supported by grants from the NIH to B.M.S, B.B.L and E.N.O. J.L. was supported by a postdoctoral fellowship from the American Heart Association.

\section{Competing interests statement}

The authors declare that they have no competing financial interests.

Correspondence and requests for materials should be addressed to B.M.S.

(e-mail: bruce_spiegelman@dfci.harvard.edu).

\title{
A new hominid from the Upper Miocene of Chad, Central Africa
}

Michel Brunet, Franck Guy, David Pilbeam, Hassane Taisso Mackaye, Andossa Likius, Djimdoumalbaye Ahounta, Alain Beauvilain, Cécile Blondel, Hervé Bocherens, Jean-Renaud Boisserie Louis De Bonis, Yves Coppens, Jean Dejax, Christiane Denys, Philippe Duringer, Véra Eisenmann, Gongdibé Fanone, Pierre Fronty, Denis Geraads, Thomas Lehmann, Fabrice Lihoreau, Antoine Louchart, Adoum Mahamat, Gildas Merceron, Guy Mouchelin, Olga Otero, Pablo Pelaez Campomanes, Marcia Ponce De Leon, Jean-Claude Rage, Michel Sapanet, Mathieu Schuster, Jean Sudre, Pascal Tassy, Xavier Valentin, Patrick Vignaud, Laurent Viriot, Antoine Zazzo \& Christoph Zollikofer

Nature 418, 145-151 (2002).

Owing to an editorial oversight, the sentence in the second column of page 150 that reads 'Lower $\mathrm{c}$ and the lower and upper premolars each have three pulp canals and two roots' is in error. Instead, it should read 'Lower and upper premolars each have three pulp canals and two roots'. 